\title{
ОБСЕ: ПОЗИТИВНЫЕ СДВИГИ
}

В Организации по безопасности и сотрудничеству в Европе в последнее время стали всё заметнее проявляться новые конструктивные тенденции. В её работе ощущается растущее стремление способствовать оздоровлению обстановки в Европе.

Примером тому служит последнее, 25-е по счёту, заседание Совета министров иностранных дел стран - членов ОБСЕ, проходившее в Милане 6-7 декабря 2018 г.

Отличительная особенность этой сессии - большое число совместных резолюций, заявлений, решений. Темы этих 11 документов сто́ит просто перечислить (по очерёдности). Поддержка прогресса в приднестровском урегулировании. Урегулирование в Нагорном Карабахе. Безопасность и сотрудничество в Средиземноморье. Лёгкое стрелковое оружие. Ситуация вокруг Договора о ракетах средней и меньшей дальности. Роль молодёжи в содействии миру и безопасности. Развитие человеческого капитала. Цифровая экономика. Безопасность журналистов. Борьба с насилием в отношении женщин. Борьба против детского трафикинга.

Решения, конечно, сильно различаются по своей значимости и важности. Но не это главное, а то, что они были согласованно приняты всеми 57 членами ОБСЕ. Стоит напомнить, что у организации есть ещё 11 партнёров, которые внимательно прислушиваются к её решениям и общему духу её заседаний. Партнёры дальние, такие как Япония, Южная Корея, Австралия, Таиланд, или ближние, как Израиль, Египет, ещё ряд стран Азии и Африки.

Итоги заседания положительно оценил министр иностранных дел РФ Сергей Лавров. Члены делегации, правда, выражали сожаление, что ряд важных предложений России приняты не были. О том же говорили и другие делегации. Это проза современной международнополитической жизни. Что-то удаётся, что-то нет.

Но главное - почти полдюжины совместных решений, принятых во всех трёх «корзинах» ОБСЕ - политической, экономической, гуманитарной.

Всё это - важное, но не единственное новшество в деятельности ОБСЕ. Развёртывается и другая работа.

Стоит в этой связи обратить внимание на новую интересную тенденцию - обращение к прошлому, к тем временам, когда ОБСЕ двигалось буквально от успеха к успеху, а европейская безопасность укреплялась всеми её участниками совместными усилиями.

Недавно ОБСЕ выпустила доклад со знаковым названием «Дорога к Парижской хартии. Исторические повествования и уроки для сегодняшней ОБСЕ», подготовленный Сообществом научных центров и академических институтов, ассоциированных с ОБСЕ (с ним взаимодействует Российский Совет по международным делам). Доклад был инициирован Германией во время её председательства в ОБСЕ и поддержан рядом других стран-членов. В докладе подробно анализируется история Парижского саммита 1990 г., который, как тогда отмечалось, положил конец холодной войне.

\footnotetext{
(C) Журкин Виталий Владимирович - доктор исторических наук, академик РАН, почётный директор Института Европы РАН. Aдpec: 125009, Россия, Москва, ул. Моховая, д. 11, стр. 3. E-mail: zhurvit@ rambler.ru
}

DOI: http://dx.doi.org/10.15211/vestnikieran1201945 
Слов нет, в сегодняшней Европе пока доминируют негативные тенденции, острые противоречия, особенно в сфере европейской безопасности. Но, как справедливо напоминает доклад ОБСЕ, такие периоды бывали и в истории, и их сменяли времена конструктивного сотрудничества. Дорога к таким временам прокладывалась совместными усилиями, позитивными сдвигами, как большими, так и малыми. Этот исторический опыт вселяет надежду.

\section{OSCE: positive changes}

Author. Vitaly Zhurkin, Academician of Russian Academy of Sciences, Honorary Director of the Institute of Europe, Russian Academy of Sciences. Address: 11-3, Mokhovaya str., Moscow, Russia, 125009. E-mail: zhurvit@rambler.ru

Abstract. In the article analyzed the positive tendencies in the activity of the Organization for Security and Co-operation in Europe (OSCE). The author emphasized new political, economic, cultural initiatives of organization, the appeal to the past experience of the mutual efforts on the strengthening of the European security. The special attention payed to the "Road to the Paris Charter. The historical narrative and lessons for the OSCE today".

Key words: OSCE, EU, European Security, Paris Charter, Russia.

DOI: http://dx.doi.org/10.15211/vestnikieran1201945 